\title{
Assessment of tissular integrity in patients with diabetic foot
}

\author{
Avaliação da integridade tissular de pacientes com pé diabético \\ Evaluación de la integridad tisular de pacientes con pie diabético
}

Paula Vitória Costa Gontijo'
ORCID: 0000-0002-9661-4263

Lívia Maia Pascoal'

ORCID: 0000-0003-0876-3996

Leonardo Hunaldo dos Santos' ORCID: 0000-0003-2280-4643

Francisca Aline Arrais Sampaio Santos' ORCID: 0000-0002-4763-2537

Isaura Letícia Tavares Palmeira Rolim" ORCID: 0000-0002-8453-2543

Marcelino Santos Neto' ORCID: 0000-0002-6105-1886

Paula dos Santos Brito' ORCID: 0000-0002-4973-8693

'Universidade Federal do Maranhão. Imperatriz, Maranhão, Brazil. "Universidade Federal do Maranhão. São Luís, Maranhão, Brazil.

How to cite this article:

Gontijo PVC, Pascoal LM, Santos LH, Santos FAAS, Rolim ILTP, Santos Neto M, et al. Assessment of tissular integrity in patients with diabetic foot. Rev Bras Enferm. 2020;73(Suppl 5):e20200032. doi: http://dx.doi.org/10.1590/0034-7167-2020-0032

Corresponding author:

Paula Vitória Costa Gontijo

E-mail: paulagontijo17@hotmail.com

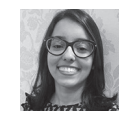

EDITOR IN CHIEF: Antonio José de Almeida Filho ASSOCIATE EDITOR: Hugo Fernandes

Submission: $01-16-2020$

Approval: 05-24-2020

\section{ABSTRACT}

Objective: Evaluate the impairment of tissue integrity in patients with diabetic foot and verify its association with time of diagnosis of the disease. Methods: Cross-sectional study conducted with 134 patients in an outpatient clinic located in the Northeast region of Brazil. A semi-structured questionnaire was used for data collection, which was subjected to descriptive analysis and the Mann-Whitney U non-parametric test. Results: Indicators with the lowest average score were: skin temperature, sweating, skin lesions, right and left pedal pulses, right and left tibial pulses. Patients less than ten years old had worse scores on thickness, elasticity, right tibial pulse and tissue integrity. Those with a diagnosis time of more than ten years had a greater impairment of sensation and right pulse. Conclusion: All indicators showed some impairment of tissue integrity, and the time of diagnosis of the disease was associated with six of these.

Descriptors: Diabetes Mellitus; Foot; Nursing; Nursing Process; Classification.

\section{RESUMO}

Objetivo: Avaliar o comprometimento da integridade tissular de pacientes com pé diabético e verificar sua associação com tempo de diagnóstico da doença. Métodos: Estudo transversal realizado com 134 pacientes em um ambulatório localizado na região Nordeste do Brasil. Foi utilizado questionário semiestruturado para a coleta de dados, os quais foram submetidos a análise descritiva e ao teste não paramétrico U de Mann-Whitney. Resultados: Indicadores com menor escore médio foram: temperatura da pele, transpiração, lesões na pele, pulsos pediosos direito e esquerdo, pulsos tibiais direito e esquerdo. Os pacientes com menos de dez anos da doença apresentaram piores escores na espessura, elasticidade, pulso tibial direito e integridade tecidual. Já aqueles com tempo de diagnóstico superior a dez anos tiveram maior comprometimento da sensação e pulso pedioso direito. Conclusão: Todos os indicadores mostraram algum comprometimento da integridade tissular, e o tempo de diagnóstico da doença esteve associado com seis destes.

Descritores: Diabetes Mellitus; Pé; Enfermagem; Processo de Enfermagem; Classificação.

\section{RESUMEN}

Objetivo: Evaluar el comprometimiento de la integridad tisular de pacientes con pie diabético y verificar su relación con tiempo de diagnóstico de la enfermedad. Métodos: Estudio transversal realizado con 134 pacientes en un ambulatorio localizado en la región Noreste de Brasil. Ha sido utilizado cuestionario semiestructurado para la recogida de datos, los cuales han sido sometidos al análisis descriptivo y al test no paramétrico $\mathrm{U}$ de MannWhitney. Resultados: Indicadores con menor calificación media han sido: temperatura de la piel, transpiración, lesiones en la piel, pulsos poplíteos derecho e izquierdo, pulsos tibiales derecho e izquierdo. Los pacientes con menos de diez años de la enfermedad presentaron peores calificaciones en la espesura, elasticidad, pulso tibial derecho e integridad tejidual. Ya aquellos con tiempo de diagnóstico superior a diez años tuvieron mayor comprometimiento de la sensación y pulso poplíteo derecho. Conclusión: Todos los indicadores mostraron alguno comprometimiento de la integridad tisular, y el tiempo de diagnóstico de la enfermedad ha relacionado con seis de estos.

Descriptores: Diabetes Mellitus; Pie; Enfermería; Proceso de Enfermería; Clasificación. 


\section{INTRODUCTION}

The increase in the prevalence of chronic non-communicable diseases (CNCDs) has gained prominence worldwide due to its high rates of morbidity and mortality. This growth is associated with a higher life expectancy of the population and changes in food consumption and lifestyle ${ }^{(1)}$. Among the CNCDs, type 2 diabetes mellitus (DM) stands out because it reaches epidemic proportions and corresponds to about $90 \%$ of all diabetes cases. This disease is linked to the occurrence of chronic complications that cause damage to the functional capacity, autonomy and quality of life of people, generating social, psychological and economic consequences ${ }^{(2)}$.

Among such complications, it is noteworthy those related to the foot, which can be evidenced by wounds from neurological diseases, vascular and biomechanical changes. People with diabetes have a quarter of a chance of developing foot ulcers, being the main cause of non-traumatic lower limb amputations ${ }^{(3)}$.

Diabetic foot is characterized as an infectious condition, with the presence of ulcers and / or tissue destruction. This destruction is related to neuropathy with or without the presence of peripheral vascular disease. Among the main changes that can be found in the diabetic foot, we highlight diabetic peripheral neuropathy, skin changes, calluses secondary to areas of high pressure in the foot, ulcerations in the feet and peripheral arterial disease ${ }^{(4-5)}$.

Due to the complexity associated with diabetes and its complications, it is important for nurses to assess diabetic foot in order to prevent dysfunctions, promote self-care and reduce health damage. For this to occur, it is necessary to characterize the patient's health status using the proper nursing terminologies, which allow effective assistance to be carried out through evidence-based practice, aiming to achieve quality indicators. In order to facilitate the use of terminologies, the literature recommends the use of a standardized language system, which aims to cooperate with better evidence of health status ${ }^{(6)}$.

Among these systems, the Nursing Outcomes Classification (NOC) stands out, as it makes it possible to standardize the terms and document the phases of care $^{(7)}$. When using the NOC, the nurse will perform a comprehensive assistance, with a clear language, which allows the evaluation of the nursing process and has a complementary connection with the taxonomies NANDA International, Inc. and Nursing Interventions Classification $^{(8)}$. Therefore, in addition to being a nursing reference, the NOC contributes to the patient's assessment and determination of their baseline health status, which will take place from the first contact.

As complications related to diabetic foot can vary from one patient to another, the terminology of the NOC is a tool that can be used to assess the degree of impaired tissue integrity of the feet. Currently, the NOC presents eight results aimed at skin evaluation, among them the result "Tissue Integrity: skin and mucous membranes", inserted in the first edition of this taxonomy in 1997, being revised in 2004 and 2013. It is found in the domain Physiological health (II), in the class Tissue integrity (L); contains 22 indicators and two scales to measure the result ${ }^{(9)}$.

\section{OBJECTIVE}

Assess the impairment of tissue integrity in patients with diabetic foot and verify its association with the time of diagnosis of the disease.

\section{METHODS}

\section{Ethical aspects}

Data collection started after its approval by the Research Ethics Committee of the Federal University of Maranhão. Patients agreed to participate by signing the Free and Informed Consent Term (FICT). This research ensured the privacy and confidentiality of the information that was collected, as well as the patient's right to reject or abandon it at any time he deemed necessary.

\section{Study design, period and location}

This is a cross-sectional, descriptive study with a quantitative approach, developed from November 2018 to July 2019, at the diabetic foot clinic located in the Northeast region of Brazil, with patients with type 2 diabetes mellitus who were being followed up on an outpatient basis due to the need for care to treat diabetic foot. The steps of this methodology were guided by the STROBE tool.

\section{Population, inclusion and exclusion criteria}

The population consisted of all adult patients with diabetic foot who were on outpatient treatment. To estimate the sample size for the infinite population, a calculation was performed using the $G$ * Power 3.1 software ${ }^{(10)}$, using a chi-square analysis. Power was set at 0.80 , and the level of significance (a) was maintained at 0.05 (5\%). Through these calculations, the estimated sample was approximately 134 patients. Inclusion criteria were defined: having a diagnosis of type 2 diabetes mellitus and having a diabetic foot; being in outpatient treatment to treat the lesion, having only undergone a dressing; and be 18 years of age or older. Patients diagnosed with psychiatric, oncological disorders, chronic alcohol addicts and who had or were undergoing treatment for leprosy were excluded from the research.

\section{Study protocol}

Data collection was performed independently by the researcher and undergraduate Nursing students who are part of a research group, that studies nursing taxonomies. In this sense, training was carried out so that the propaedeutic methods, inherent to the interview and physical evaluation of the feet, were reviewed and standardized in order to reduce possible biases in the collection.

The data was obtained with the aid of an instrument adapted from studies ${ }^{(11,12)}$ encompassing issues related to sociodemographic and clinical variables and the nursing outcome indicators "Tissue Integrity: skin and mucous membranes"(9). To evaluate the feet of patients with type $2 \mathrm{DM}, 19 \mathrm{NOC}$ indicators and five complementary indicators were used (edema; right and left pedal pulses; and right and left tibial pulses) which, despite not being part of the nursing 
outcome in question, consist of important information to assess skin integrity as pointed out by the study ${ }^{(12)}$ performed with patients with diabetic foot. Among the indicators that make up the result "Tissue Integrity: skin and mucous membranes", mucosal lesions, skin cancers and corneal layer abrasion have not been evaluated, as these characteristics are not applicable to diabetic feet.

The data related to the physical examination were obtained with the aid of the propaedeutic methods of inspection and palpation, with the exception of the "temperature" and "sensitivity" indicators, which were measured with specific instruments. The temperature was determined with the aid of a surface thermometer, properly calibrated. The "sensation" indicator was determined based on the evaluation of tactile sensitivity of the lower limb area with the aid of Semmes-Weinstein $10 \mathrm{~g}$ monofilaments, which is a safe parameter for identifying neuropathic symptoms.. they had lesions for a period equal to or greater than 30 days (54.5\%), caused by different reasons, such as corns (19.4\%), sharp object wounds (14.2\%) and blisters (12.7\%) (Table 2).

Table 3 presents the characterization of the level of impairment of the diabetic foot in relation to tissue integrity. The indicators that presented score 1, that is, were severely compromised, were: sweating $(95.5 \%)$, skin temperature (67.9\%), left tibial pulse (64.9\%) and right (61.2\%), skin lesions (53.7\%) and right (47.8\%) and left (46.3\%).

When comparing the averages of the indicators with the time of diagnosis of DM, it was found that the patients with less than ten years of the disease had worse scores in the indicators "thickness" $(p=$ $0.004)$, "elasticity" $(p=0.028)$, "Right tibial pulse" $(p=0.029)$ and "tissue integrity" ( $p=0.043)$. In turn, those with DM diagnosis time over ten years, showed greater impairment in the indicators "sensation" ( $p=$ $0.009)$ and "right pulse" $(p=0.029)$. These data can be seen in Table 4.

\section{Analysis of results and statistics}

The data obtained were organized using Microsoft Excel version 2016, in two stages: the first was based on the patient's socioeconomic and clinical characterization; the second step involved determining the characterization of the respondents' lower limbs based on the classification of the scores obtained for the indicators according to the pre-established five-point Likert scale. After checking for errors and inconsistencies, statistical analysis of the data was performed using the IBM SPSS 24 program ${ }^{(13)}$.

In the univariate descriptive analysis, measures of relative and absolute frequencies were presented. In order to assess the association between clinical characteristics and means of clinical indicators and the result "Tissue Integrity: skin and mucous membranes", Mann-Whitney U nonparametric test (independent samples) was applied. For statistical significance, a level of $5 \%(p<0.05)$ was adopted.

\section{RESULTS}

Among the 134 patients evaluated in this research, there was a predominance of males (52.2\%), aged 60 years or over $(65.7 \%)$, retired $(55.2 \%)$, who referred to themselves as non-white (70.9\%), with a partner (56.0\%), education equivalent to elementary school (51.5\%) and family income of up to one minimum wage (41\%). Regarding life habits, a low frequency of smoking and alcohol consumption was observed in the sample evaluated, with values of $6.7 \%$ and $5.2 \%$, respectively (Table 1 ).

The evaluation of the clinical profile showed that the time of diagnosis of DM in most of the investigated patients was up to 10 years (60.4\%). In addition to DM, other chronic diseases were identified in the sample, such as hypertension (62.7\%), hypercholesterolemia (29.1\%), cardiovascular (20.1\%) and kidney problems (12.7\%). When investigated about the time they were affected with the diabetic foot, the majority stated
Table 1 - Characterization of patients with diabetic foot according to socioeconomic data, Imperatriz, Mara nhão, Brazil, 2019

\begin{tabular}{|c|c|c|c|c|}
\hline Variables & $\mathbf{n}$ & $\%$ & $95 \% \mathrm{Cl}^{\dagger}$ & \\
\hline \multicolumn{5}{|l|}{ Sex } \\
\hline Male & 70 & 52.2 & \multicolumn{2}{|l|}{$43.47-60.87$} \\
\hline Female & 64 & 47.8 & $39.12-56.5$ & \\
\hline \multicolumn{5}{|l|}{ Age } \\
\hline$<60$ years & 46 & 34.3 & \multicolumn{2}{|c|}{$26.48-43.08$} \\
\hline$\geq 60$ years & 88 & 65.7 & $56.91-73.5$ & \\
\hline \multicolumn{5}{|l|}{ Race } \\
\hline White & 39 & 29.1 & \multicolumn{2}{|c|}{ 21.74-37.68 } \\
\hline Non white & 95 & 70.9 & \multicolumn{2}{|c|}{$62.31-78.25$} \\
\hline \multicolumn{5}{|l|}{ Marital status } \\
\hline \multirow{2}{*}{$\begin{array}{l}\text { With partner } \\
\text { Without partner }\end{array}$} & 75 & 56.0 & \multicolumn{2}{|c|}{ 47.14-64.44 } \\
\hline & 59 & 44.0 & \multicolumn{2}{|c|}{$35.55-52.85$} \\
\hline \multicolumn{5}{|l|}{ Education } \\
\hline Illiterate & 34 & 25.4 & \multicolumn{2}{|c|}{ 18.43-33.75 } \\
\hline Elementary school & 69 & 51.5 & \multicolumn{2}{|c|}{$42.74-60.15$} \\
\hline Highschool & 22 & 16.4 & \multicolumn{2}{|c|}{$10.79-24.02$} \\
\hline Higher education & 9 & 6.7 & \multicolumn{2}{|c|}{$03.31-12.73$} \\
\hline \multicolumn{5}{|l|}{ Profession } \\
\hline Retired & 74 & 55.2 & \multicolumn{2}{|c|}{$46.40-63.73$} \\
\hline Active employee & 34 & 25.4 & \multicolumn{2}{|c|}{$18.43-33.75$} \\
\hline Unemployed & 10 & 7.5 & \multirow{2}{*}{\multicolumn{2}{|c|}{$\begin{array}{l}03.83-13.64 \\
07.19-18.94\end{array}$}} \\
\hline Sick leave & 16 & 11.9 & & \\
\hline \multicolumn{5}{|l|}{ Income* } \\
\hline Up to 1 minimum wage & 55 & 41.0 & \multirow{3}{*}{\multicolumn{2}{|c|}{$\begin{array}{l}32.72-49.88 \\
25.11-41.55 \\
19.09-34.54\end{array}$}} \\
\hline$\geq 1$ minimum wage $e \leq 2$ minimum wages & 44 & 32.8 & & \\
\hline 2 or more minimum wages & 35 & 26.2 & & \\
\hline \multicolumn{5}{|l|}{ Lives alone } \\
\hline Yes & 25 & 18.7 & \multirow{2}{*}{\multicolumn{2}{|c|}{$\begin{array}{l}12.65-26.50 \\
73.49-87.34\end{array}$}} \\
\hline No & 109 & 81.3 & & \\
\hline \multicolumn{5}{|l|}{ Has children } \\
\hline Yes & 125 & 93.3 & \multicolumn{2}{|c|}{$87.26-96.68$} \\
\hline No & 9 & 6.7 & $03.31-12.73$ & \\
\hline Smoker & & & & \\
\hline Yes & 9 & 6.7 & $03.31-12.73$ & \\
\hline No & 125 & 93.3 & $87.26-96.68$ & \\
\hline Drinker & & & & \\
\hline Yes & 7 & 5.2 & $02.30-10.8$ & \\
\hline No & 127 & 94.8 & $89.13-97.6$ & \\
\hline Variable & Average & $\begin{array}{l}\text { Standard } \\
\text { deviation }\end{array}$ & $\mathbf{P}^{\prime} 5^{\ddagger} \mathbf{P}^{\prime} 0^{\S}$ & P75" \\
\hline Age & 63.5 & 12.8 & 56.064 .0 & 74.0 \\
\hline
\end{tabular}

interval. $\neq P 25: 25$ th percentile. \$P50: 50 th percentile. $\| P 75: 75$ th percentile. 
Table 2 - Characterization of patients with diabetic foot according to clinical data, Imperatriz, Maranhão, Brazil, 2019

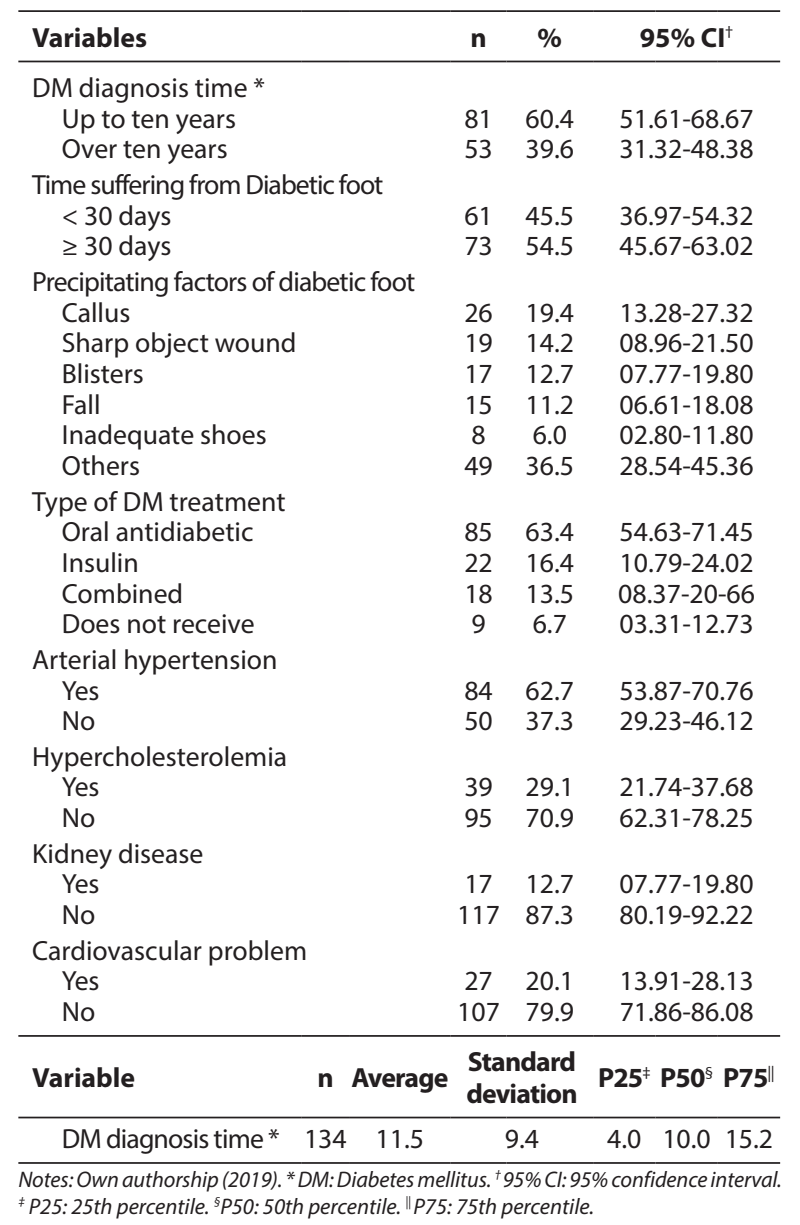

Table 4 - Comparison between the averages of the Nursing Outcomes Classification indicators with the time of diagnosis of diabetes mellitus, Imperatriz, Maranhão, Brazil, 2019

\begin{tabular}{|c|c|c|c|c|c|}
\hline \multirow{3}{*}{ NOC INDICATORS } & \multicolumn{4}{|c|}{ DM diagnosis time (categorized) } & \multirow{3}{*}{$\begin{array}{c}p \\
\text { value }\end{array}$} \\
\hline & \multicolumn{2}{|c|}{ Up to tem years } & \multicolumn{2}{|c|}{ More than ten years } & \\
\hline & Average & $\begin{array}{l}\text { Standard } \\
\text { deviation }\end{array}$ & Average & $\begin{array}{l}\text { Standard } \\
\text { deviation }\end{array}$ & \\
\hline Skin temperature & 1.88 & 1.44 & 2.13 & 1.68 & 0.481 \\
\hline Sensation & 2.74 & 1.21 & 2.19 & 1.16 & 0.009 \\
\hline Elasticity & 3.11 & 1.39 & 3.62 & 1.40 & 0.028 \\
\hline Hidration & 3.35 & 1.24 & 3.23 & 1.54 & 0.928 \\
\hline Transpiration & 1.10 & 0.62 & 1.28 & 1.01 & 0.170 \\
\hline Texture & 2.73 & 1.13 & 2.83 & 1.10 & 0.566 \\
\hline Thickness & 3.01 & 1.67 & 3.91 & 1.57 & 0.004 \\
\hline Tissue perfusion & 2.09 & 0.87 & 2.30 & 1.22 & 0.482 \\
\hline Hair growth on the skin & 2.96 & 1.47 & 2.96 & 1.49 & 0.950 \\
\hline Tissue integrity & 2.54 & 0.98 & 2.81 & 0.94 & 0.043 \\
\hline Abnormal pigmentation & 3.41 & 1.49 & 3.34 & 1.27 & 0.684 \\
\hline Skin lesions & 2.06 & 1.41 & 2.34 & 1.40 & 0.190 \\
\hline Scar tissue & 3.14 & 1.14 & 3.15 & 1.23 & 0.927 \\
\hline Skin peeling & 3.32 & 1.71 & 3.70 & 1.61 & 0.243 \\
\hline Skin cracks & 4.53 & 0.67 & 4.66 & 0.65 & 0.153 \\
\hline Erythema & 3.41 & 1.56 & 3.43 & 1.53 & 0.947 \\
\hline Paleening & 4.14 & 1.37 & 4.13 & 1.07 & 0.215 \\
\hline Necrosis & 4.21 & 1.39 & 3.87 & 1.70 & 0.289 \\
\hline Hardening & 3.11 & 1.66 & 3.40 & 1.59 & 0.351 \\
\hline Edema & 3.11 & 1.62 & 3.55 & 1.60 & 0.151 \\
\hline Right Pedal Pulse & 2.73 & 1.72 & 2.04 & 1.56 & 0.029 \\
\hline Left Pedal Pulse & 2.80 & 1.81 & 2.24 & 1.57 & 0.132 \\
\hline Right tibial pulse & 1.91 & 1.42 & 1.94 & 1.50 & 0.029 \\
\hline Left tibial pulse & 2.09 & 1.63 & 1.73 & 1.30 & 0.132 \\
\hline
\end{tabular}

Notes: NOC - Nursing Outcomes Classification. * P-value of the Mann-Whitney test.

Table 3 - Characterization of patients with diabetic foot regarding the level of impairment of the nursing outcome indicators "Tissue Integrity: skin and mucous membranes", Imperatriz, Maranhão, Brazil, 2019

\begin{tabular}{|c|c|c|c|c|c|c|c|c|c|c|c|}
\hline \multirow{3}{*}{ NOC indicators } & \multicolumn{10}{|c|}{ NOC Likert Scale } & \multirow{3}{*}{ Average } \\
\hline & \multicolumn{2}{|c|}{$\begin{array}{c}\text { Severely } \\
\text { compromised }\end{array}$} & \multicolumn{2}{|c|}{$\begin{array}{c}\text { Very } \\
\text { compromised }\end{array}$} & \multicolumn{2}{|c|}{$\begin{array}{l}\text { Moderately } \\
\text { compromised }\end{array}$} & \multicolumn{2}{|c|}{$\begin{array}{l}\text { Lightly } \\
\text { compromised }\end{array}$} & \multicolumn{2}{|c|}{$\begin{array}{c}\text { Not } \\
\text { compromised }\end{array}$} & \\
\hline & $\mathbf{n}$ & $\%$ & $\mathbf{n}$ & $\%$ & $\mathbf{n}$ & $\%$ & $\mathbf{n}$ & $\%$ & $\mathbf{n}$ & $\%$ & \\
\hline Skin temperature & 91 & 67.9 & 5 & 3.7 & 6 & 4.5 & 14 & 10.4 & 18 & 13.4 & 1.98 \\
\hline Sensation & 39 & 29.1 & 29 & 21.6 & 23 & 17.2 & 43 & 32.1 & - & - & 2.52 \\
\hline Elasticity & 21 & 15.7 & 23 & 17.2 & 15 & 11.2 & 43 & 32.1 & 32 & 23.9 & 3.31 \\
\hline Hidration & 26 & 19.4 & 7 & 5.2 & 26 & 19.4 & 51 & 38.1 & 24 & 17.9 & 3.30 \\
\hline Transpiration & 128 & 95.5 & - & - & - & - & 1 & 0.7 & 5 & 3.7 & 1.17 \\
\hline Texture & 23 & 17.2 & 29 & 21.6 & 42 & 31.3 & 36 & 26.9 & 4 & 3.0 & 2.77 \\
\hline Thickness & 23 & 17.2 & 39 & 29.1 & 3 & 2.2 & 4 & 3.0 & 65 & 48.5 & 3.37 \\
\hline Tissue perfusion & 38 & 28.4 & 53 & 39.6 & 29 & 21.6 & 10 & 7.5 & 4 & 3.0 & 2.17 \\
\hline Hair growth on the skin & 37 & 27.6 & 13 & 9.7 & 25 & 18.7 & 36 & 26.9 & 23 & 17.2 & 2.96 \\
\hline \multirow[t]{3}{*}{ Tissue integrity } & 9 & 6.7 & 58 & 43.3 & 47 & 35.1 & 11 & 8.2 & 9 & 6.7 & 2.65 \\
\hline & \multicolumn{2}{|c|}{ Severe } & \multicolumn{2}{|c|}{ Substantial } & \multicolumn{2}{|c|}{ Moderate } & \multicolumn{2}{|c|}{ Light } & \multicolumn{2}{|c|}{ None } & Average \\
\hline & $\mathbf{n}$ & $\%$ & $\mathbf{n}$ & $\%$ & $\mathbf{n}$ & $\%$ & $\mathbf{n}$ & $\%$ & $\mathbf{n}$ & $\%$ & Average \\
\hline Abnormal pigmentation & 8 & 6.0 & 47 & 35.1 & 9 & 6.7 & 26 & 19.4 & 44 & 32.8 & 3.38 \\
\hline Skin lesions & 72 & 53.7 & 15 & 11.2 & 1 & 0.7 & 44 & 32.8 & 2 & 1.5 & 2.17 \\
\hline Scar tissue & 12 & 9.0 & 29 & 21.6 & 39 & 29.1 & 36 & 26.9 & 18 & 13.4 & 3.14 \\
\hline Skin peeling & 26 & 19.4 & 25 & 18.7 & 10 & 7.5 & 6 & 4.5 & 67 & 50.0 & 3.47 \\
\hline Skin cracks & - & - & 1 & 0.7 & 10 & 7.5 & 33 & 24.6 & 90 & 67.2 & 4.58 \\
\hline Erythema & 27 & 20.1 & 14 & 10.4 & 16 & 11.9 & 30 & 22.4 & 47 & 35.1 & 3.42 \\
\hline Paleening & 9 & 6.7 & 12 & 9.0 & 7 & 5.2 & 30 & 22.4 & 76 & 56.7 & 4.13 \\
\hline Necrosis & 20 & 14.9 & 9 & 6.7 & 3 & 2.2 & 11 & 8.2 & 91 & 67.9 & 4.07 \\
\hline Hardening & 35 & 26.1 & 10 & 7.5 & 29 & 21.6 & 10 & 7.5 & 50 & 37.3 & 3.22 \\
\hline Edema* & 30 & 22.4 & 18 & 13.4 & 23 & 17.2 & 10 & 7.5 & 53 & 39.6 & 3.28 \\
\hline Right Pedal Pulse* & 64 & 47.8 & 17 & 12.7 & 3 & 2.2 & 17 & 12.7 & 29 & 21.6 & 2.46 \\
\hline Left Pedal Pulse* & 62 & 46.3 & 16 & 11.9 & 4 & 3.0 & 15 & 11.2 & 35 & 26.1 & 2.58 \\
\hline Right tibial pulse* & 82 & 61.2 & 20 & 14.9 & 2 & 1.5 & 11 & 8.2 & 16 & 11.9 & 1.92 \\
\hline Left tibial pulse* & 87 & 64.9 & 13 & 9.7 & 3 & 2.2 & 10 & 7.5 & 19 & 14.2 & 1.95 \\
\hline
\end{tabular}

Notes: NOC - Nursing Outcomes Classification. ${ }^{*}$ Clinical indicators, not contained in the NOC. 


\section{DISCUSSION}

The predominance of male diabetic foot patients identified in this research corroborates another study carried out in an outpatient clinic for the treatment of diabetic foot located in a municipality in Paraíba, which also presented a higher frequency of such involvement among patients in this group $(60.6 \%)^{(14)}$. Men are the majority among hospitalized patients with foot ulcers, and this change is associated with high levels of disability, such as amputation due to the high degree of impairment of the lower limb $b^{(15)}$.

The fact that men are more affected by the diabetic foot may be due to not making changes in lifestyle, which are necessary to reduce the glycemic index, and because they do not routinely develop self-care practices with their feet to prevent the occurrence of lesions ${ }^{(14)}$. As a result, being male has been identified in the literature as a risk factor for non-traumatic amputations ${ }^{(16)}$.

Regarding age, a study ${ }^{(17)}$ performed with hospitalized patients with diabetic foot obtained a result similar to this research, in which diabetic patients were aged 60 years or over. This finding is justified due to the higher life expectancy of the population and, consequently, greater metabolic disorder, which is associated with high rates of chronic non-communicable diseases. In addition, older people live with the disease for a prolonged period, which makes them more exposed to the risks of complications ${ }^{(18)}$.

Among the comorbidities that affect patients with diabetic foot, systemic arterial hypertension stands out, which was the most frequent in the investigated sample. About this, authors ${ }^{(19)}$ claim that diabetic patients are more susceptible to the occurrence of cardiovascular diseases. In addition, diabetic patients with associated diseases are at increased risk of developing foot lesions or ulcers ${ }^{(20)}$

The time of diagnosis of diabetes mellitus is a risk factor for the occurrence of diabetic foot, since the attitude of self-care decreases among patients who have a longer time of diagnosis. This occurs because they are more vulnerable to the occurrence of limitations related to the disease, which contributes to decrease the motivation of patients to adhere to medication and non-medication treatment ${ }^{(21)}$. However, this data differs from that found in the present investigation, since most of the patients evaluated had a time of diagnosis of the disease of less than ten years. Another data identified in this study was that a significant portion of the patients had the foot lesion installed for a period equal to or greater than 30 days, making them more susceptible to serious infections and increasing the healing time ${ }^{(22)}$.

The indicators that revealed the highest level of impairment in the patients with diabetic foot evaluated were: sweating, skin temperature, skin lesions, tibial and pedal pulses. The decrease or absence of perspiration is a frequent feature in the diabetic foot due to constant hyperglycemia compromising the autonomic nerve endings. This alteration causes anhidrosis, which makes the feet drier and more susceptible to the occurrence of cracks ${ }^{(23)}$.

Another characteristic common to patients with diabetic foot is peripheral vascular disease, which compromises the blood circulation of the lower limbs and limits the supply of oxygen and nutrients to the tissue, causing a decrease in tibial and pedal pulses and hindering the healing process of foot lesions ${ }^{(24)}$. This circulatory impairment interferes with the regulation of tissue temperature in the foot, as it is influenced by blood vessels and peripheral nerves ${ }^{(25)}$. Therefore, it is believed that this fact may justify the low tissue temperature and, consequently, worse NOC scores identified in the evaluated patients.

Still, a point to be highlighted in this research is that all the indicators evaluated showed some degree of impairment, which varied between scores 1 and 4, and the most frequent were: sensation, texture, tissue perfusion and tissue integrity. Such findings differ from the study ${ }^{(26)}$ performed with diabetic patients, which clinically validated the Tissue Integrity nursing result, since the indicators "hardening" (94\%) and "edema" (89\%) were the most frequent among those who presented some degree of impairment.

In addition, this study ${ }^{(26)}$ observed that the indicators "skin lesions" and "necrosis" did not show impairment in 91\% and 98\%, respectively, of the investigated sample. On the other hand, in this investigation, the indicators that showed the highest frequency of score 5, that is, absence of involvement, were: necrosis, cracking of the skin and paleness. This divergence of results may be associated with the fact that the study ${ }^{(26)}$ previously mentioned was developed in an outpatient clinic for patients with diabetes mellitus who did not have ulcerative lesions on their feet.

As for the association between DM diagnosis time and the indicators evaluated, it was observed that the "skin elasticity" indicator had the lowest average among patients who had diabetes for less than ten years. Although authors ${ }^{(27)}$ claim that the occurrence of complications is related to the longer the person lives with the disease, the result identified may be related to the fact that patients with recent diagnosis do not develop activities that stimulate sweating and aim at the body's water balance ${ }^{(28)}$. The reduction in tissue elasticity is a complication caused by hyperglycemia, which occurs due to decreased humidity and dehydration, changing the distribution of plantar pressure ${ }^{(28-29)}$.

Regarding "tissue integrity", it was found that patients with shorter time since diagnosis of the disease showed greater impairment of this indicator. It is believed that this result occurs due to the appearance of complications more easily identified from clinical exposure and the treatment that patients receive ${ }^{(30)}$.

An issue also to be highlighted is the greater impairment of the right tibial pulse among patients with a diagnosis time of less than ten years and of the right pedal pulse in patients who have lived with the disease for more than ten years. To justify this finding, the literature points out that circulatory manifestations usually develop after ten years of disease evolution, however these can also affect patients with inadequate control of diabetes mellitus, regardless of the time of diagnosis ${ }^{(31)}$. In addition, the aging process, associated with the presence of other chronic diseases such as cardiovascular diseases, make diabetic patients more susceptible to the occurrence of changes in the pulses ${ }^{(32)}$.

Another frequent change in patients with longer disease duration is peripheral neuropathy, and this fact was identified in this research, since the "sensation" indicator revealed a lower average. This result differs from that found in another study ${ }^{(12)}$, who identified in the first evaluation of the feet of diabetic patients the best average of the "sensation" indicator (3.53), although a comparison was not made between the time of diagnosis of the disease. This change occurs due to lesion to the axons and myelin sheaths of 
the peripheral nerves, which results in reduced plantar sensitivity and can cause complete anesthesia of the foot ${ }^{(4)}$.

Loss of sensation makes diabetic patients more vulnerable to the development of traumatic lesions, which are sometimes imperceptible and delay the search for a specialized health service. These lesions can occur due to the use of tight shoes, washing the feet with hot water, inappropriate use of chemicals to remove calluses and, above all, due to sharp object wounds such as nails and broken glass ${ }^{(4)}$.

\section{Study limitations}

As limitations of this study, we highlight the few studies available in the literature that associate the time of diagnosis of diabetes mellitus with the indicators of the nursing result "Tissue Integrity: skin and mucous membranes". Also, the fact that the data collection was carried out by different researchers may have generated divergence in the tissue evaluation of the diabetic foot, although training was carried out to minimize this consequence.

\section{Contributions to the field of Nursing}

The results obtained can help the nurse's performance by allowing to identify which characteristics of the diabetic foot are most affected and whether the time of diagnosis of the disease makes these patients more susceptible to the development of complications. This information will favor the creation of parameters for the evaluation of chronic wounds using the NOC. In addition, through this information, interventions can be carried out in order to promote better evolution of NOC indicators.

\section{CONCLUSION}

The use of a specific nursing terminology, such as NOC, made it possible to assess the tissue integrity of the skin of patients with diabetic foot and to identify that the time of diagnosis equal to or greater than ten years influenced the level of impairment of the indicators that characterized the diabetic foot.

Among these indicators, those with the lowest average, ranging from severely impaired to very impaired, were: skin temperature; perspiration; skin lesions; right and left pedal pulses; and right and left tibial pulses. All other indicators evaluated showed some degree of impairment that varied from mild to severely impaired. The time of diagnosis of the disease was associated with the impairment of these indicators: thickness, elasticity, right tibial pulse, tissue integrity, sensation and right pedal pulse.

\section{FUNDING}

Foundation for the Support of Research and Scientific and Technological Development of Maranhão - FAPEMA and the Coordination for the Improvement of Higher Education Personnel - CAPES.

\section{REFERENCES}

1. Costa AF, Flor LS, Campos MR, Oliveira AF, Costa MFS, Silva RS, et al. Burden of type 2 diabetes mellitus in Brazil. Cad Saúde Pública [Internet]. 2017 [cited 2019 Oct 10];33(2):e00197915. Available from:http://www.scielo.br/pdf/csp/v33n2/1678-4464-csp-33-02-e00197915.pdf

2. Ogurtsova K, Rocha Fernandes JD, Huang Y, Linnenkamp U, Guariguata L, Cho NH, et al. IDF Diabetes Atlas: Global estimates for the prevalence of diabetes for 2015 and 2040. Diabetes Res Clin Pract[Internet]. 2017 [cited 2019 Oct 10];128:40-50. doi: 10.1016/j.diabres.2017.03.024

3. Centers for Disease Control and Prevention (CDC). National diabetes fact sheet: national estimates and general information on diabetes and prediabetes in the United States, 2011. Atlanta, GA: US Department of Health and Human Services, Centers for Disease Control and Prevention. 2012.

4. Duarte N, Gonçalves A. Pé diabético. Angiologia e Cirurgia Vascular [Internet]. 2011 [cited 2019 Dec 10];7(2):65-79. Available from: http:// www.scielo.mec.pt/pdf/ang/v7n2/v7n2a02.pdf

5. Bowling FL, Rashid ST, Boulton AJM. Preventing and treating foot complications associated with diabetes mellitus. Nature Reviews Endocrinology [Internet]. 2015 [cited 2019 Dec 10];11(10):606. Available from: https://www.nature.com/articles/nrendo.2015.130

6. Carvalho EC. Contribuição da classificação dos resultados de enfermagem na assistência. Arq Ciên Saúde [Internet]. 2017 [cited 2019 Dec 20];24(1):1-2. Available from: http://www.cienciasdasaude.famerp.br/index.php/racs/article/view/771/677

7. Carvalho EC, Eduardo AHA, Romanzini A, Simão TP, Zamaioli CM, Garbuio DC, et al. Correspondence Between NANDA International Nursing Diagnoses and Outcomes as Proposed by the Nursing Outcomes Classification. Int J Nurs Know. 2018;29(1):66-78. doi: $10.1111 / 2047-3095.12135$

8. Schulz RS, Faleiro TB, Ribeiro JJG, Pinto MBS, Santana MS, Queiroz PE. Nursing care systematization by NANDA_NIC_NOC strategy in practice. Rev Enferm. 2016;10(6):2159-66. doi: 10.5205/1981-8963-v10i6a11230p2159-2166-2016

9. Moorhead S, Johnson M, Mass ML, Swanson E. Classificação dos resultados de enfermagem - NOC 5a ed. Rio de Janeiro: Elsevier; 2016.

10. Faul F, Erdfelder E, Lang AG, Buchner A. G*Power 3: A flexible statistical power analysis program for the social, behavioral, and biomedical sciences. Behav Res Methods. 2007;39:175-91. Available from: https://link.springer.com/article/10.3758/BF03193146

11. Santos FAAS. Construção e investigação da validade de definições conceituais e operacionais do resultado de enfermagem integridade tissular: um estudo com portadores de úlcera venosa[Tese]. Fortaleza. Universidade Federal do Ceará; 2011.

12. Silva NCM. Efeitos da reflexologia podal sobre os pés de portadores de diabetes mellitus tipo 2: um ensaio randomizado[Dissertação]. Alfenas. Universidade Federal de Alfenas; 2014. 
13. IBM Corp. Released. IBM SPSS Statistics for Windows, Version 24.0. Armonk, NY: IBM Corp; 2016.

14. Andrade LL, Carvalho GCP, Valentim FAAA, Siqueira WA, Melo FMAB, Costa MML. Caracterização e tratamento de úlceras do pé diabético em um ambulatório. Rev Pesqui: Cuid Fundam. 2019;11(1):124-8. doi: 10.9789/2175-5361.2019.v1111.124-128

15. Pedras S, Carvalho R, Pereira MG. Sociodemographic and clinical characteristics of patients with diabetic foot ulcer. Rev Assoc Med Bras. 2016;62(2):171-8. doi: 10.1590/1806-9282.62.02.171

16. Morais GFC, Soares MJGO, Costa MML, Santos IBC. O diabético diante do tratamento, fatores de risco e complicações crônicas. Rev Enferm UERJ [Internet]. 2009 [cited 2019 Dec 22];17(2):240-5.Available from: http://www.facenf.uerj.br/v17n2/v17n2a18.pdf

17. Oliveira JC, Taquary SAS, Barbosa AM, Veronesi RJB. Pé diabético e amputações em pessoas internadas em hospital público: estudo transversal. ABCS Health Sci. 2016;41(1). doi: 10.7322/abcshs.v41i1.843

18. Souza S, Silva J, Santos M. Análise do perfil da hipertensão e diabetes no Município de Jequié-BA. Interscientia [Internet]. 2016 [cited 2020 Jan 5];2(1):63-6. Available from: https://periodicos.unipe.br/index.php/interscientia/article/view/59

19. Scheffel RS, Bortolanza D, Weber CS, Costa LA, Canani LH, Santos KG, et al. Prevalence of micro and macro angiopatic chronic complications and their risk factors in the care of out patients with type 2 diabetes mellitus. Rev Assoc Med Bras. 2004;50(3):263-7. doi: 10.1590/ S0104-42302004000300031

20. Sarinnapakorn V, Sunthorntepwarakul T, Deerochanawong C, Niramitmahapanya S, Napartivaumnuay N. Prevalence of diabetic foot ulcers and risk classifications in type 2 diabetes mellitus patients at Rajavithi Hospital. J MedAssocThai [Internet]. 2016 [cited 2020 Jan 5];99(2):S99-S105. Available from: http://www.thaiscience.info/Journals/Article/JMAT/10986038.pdf

21. Tanqueiro MTOS. A gestão do autocuidado nos idosos com diabetes: revisão sistemática da literatura. Rev Enferm Ref. 2013;9:151-60. doi: 10.12707/RIII1202

22. Targino IG, Souza JSO, Santos NMG, Davim RMB, Silva RAS. Factors related to the development of ulcers in patients with diabetes mellitus. Rev Pesqui: Cuid Fundam. 2016;8(4):4929-34. doi: 10.9789/2175- 5361.2016.v8i4.4929-4934

23. Silva CAM, Sousa D, Almeida DSC, Venancio MIL. Pé diabético e avaliação do risco de ulceração. Rev Enferm Ref. 2014;serIV(1):153-61. doi: $10.12707 /$ RIII12166

24. Levin ME. Foot lesions in patients with diabetes mellitus. Endocrinol Metabol Clin North Am. 1996;25(2): 447-62. doi: 10.1016/ s0889-8529(05)70333-9

25. Silva M, Almeida M, Panato B, Siqueira A, Silva M, Reisderfer L. Clinical applicability of nursing outcomes in the evolution of orthopedic patients with Impaired Physical Mobility. Rev Latino-Am Enfermagem [Internet]. 2015 [cited 2020 Jan 5];23(1):51-8. Available from: https:// www.revistas.usp.br/rlae/article/view/100037/98649

26. Silva NCM, Kumakura ARSO, Moorhead S, Pace AE, Carvalho EC. Clinical Validation of the Indicators and Definitions of the Nursing Outcome"Tissue Integrity: Skin and Mucous Membranes" in People With diabetes mellitus. Int J Nurs Knowl. 2017;28(4):165-70. doi: $10.1111 / 2047-3095.12150$

27. Cortez DC, Reis IA, Souza DAS, Macedo MML, Torres HC. Complications and the time of diagnosis of diabetes mellitus in primary care. Acta Paul Enferm. 2015;28(3):250-5. doi: 10.1590/1982-0194201500042

28. Lindgren L, Lehtipalo S, Winso O, Karlsson M, Wiklund U, Brulin C. Touch massage: a pilot study of a complex intervention. Nurs Crit care. 2013;18(6):269-77. doi: 10.1111/nicc.12017

29. Sawacha Z, Guarneri G, Cristoferi G, Guiotto A, Avogaro A, Cobelli C. Integrated kinematics-kinetics-plantar pressure data analysis: a useful tool for characterizing diabetic foot biomechanics. Gait Posture. 2012;36(1):20-6. doi: 10.1016/j.gaitpost.2011.12.007

30. Nagase T, Sanada H, Takehara K, Oe M, Lizaka S, Ohashi Y, et al. Variations of plantar thermographic patterns in normal controls and nonulcer diabetic patients: Novel classification using angio some concept. J Plast Reconstr Aesthet Surg. 2011;64(7):860-6. doi: 10.1016/j. bjps.2010.12.003

31. Oliveira JC, Taquary SAS, Barbosa AM, Veronezi RJB. Pé diabético: perfil sociodemográfico e clínico de pacientes hospitalizados. Rev Bras Ciênc Saúde. 2018;22(1):15-20. doi: 10.22478/ufpb.2317-6032.2018v22n1.23034

32. Piza LF, Eleotério BD, Gomes LC. Avaliação dos pés de idosos com diabetes mellitus: estudo descritivo. Enferm Brasil [Internet]. 2018 [cited 5 Jan 2020];17(3):245-52. Available from: https://www.researchgate.net/profile/Lilian_Gomes4/publication/327476876_ARTIGO_ORIGINAL_ Avaliacao_dos_pes_de_idosos_com_diabetes_mellitus_estudo_descritivo/links/5b9164c0a6fdccfd541ef754/ARTIGO-ORIGINAL-Avaliacaodos-pes-de-idosos-com-diabetes-mellitus-estudo-descritivo.pdf 